\title{
"What is the meaning of all this gluttony?": Edgeworth, The Victorians, C. S. Lewis and a Taste for Fantasy
}

\author{
Lynne Vallone
}

\begin{abstract}
No book is really worth reading at the age of ten which is not equally (and often far more) worth reading at the age of fifty-except, of course, books of information. The only imaginative works we ought to grow out of are those which it would have been better not to have read at all. A mature palate will probably not much care for creme de menthe: but it ought still to enjoy bread and butter and honey.

(C.S. Lewis 1966a, p.15)
\end{abstract}

$\mathrm{I}$ $n$ the well-known quotation cited above, Lewis connects the physical sensation of 'taste' (registered Ly the 'palate') with literary judgements made about children's literature. Taste naturally leads us to food, the 'bread and butter and honey' that Lewis believes all people should enjoy at any age. In writing about the novel. Italian literary critic Gian-Paolo Biasin notes that the representation of food [functions as] a metonymy of the real...' (Biasin 1993, p.4). The same could be argued, I believe. within fantasy literature: food connects the fantastic world with the 'real' one (both inside the novel - for example. England during the Second World War in The Lion, the Witch and the Wardrobe - and outside of the novel. for its readers). Because eating is a required act by any character, whether in a 'real' or a fantastic realm. food often functions as a marker of the 'commonplace' actual world interjected into the fantastic one (Egoff 1988. p.153). This mimetic effect is less the case in fantasy worlds that do not connect with 'the real' through some kind of portal (such as Tolkien's wholly separate Middle Earth or Lloyd Alexander's Prydain), but certainly in dream-scapes such as Carroll's Wonderland, or parallel worlds such as Lewis's Narnia, the negotiation of food and the issues that surround it (for example appetite and table manners) reveal real-world ideologies of gender. morality. child conduct, and, ultimately, community, within the fantastic realm.

The food metaphor 'speaks' synaesthetically within literature (we taste the words with our eyes)-but not in one voice or to one purpose. Ionathan Langford notes that the cultural discourse of food is a multivalenced one. involving as it does questions of incorporation and containment... (Langford 1996, p.119). And, as Sarah
Sceats suggests in her study of food in contemporary women's fiction,

Food itself is not bound within any single discourse, but impregnated with meanings from the many and various frameworks within which it figures - and this is a major reason why it is so rich a resource for writers.

(Sceats 2000, p.126)

The inclusion of scenes of eating. appetite, fasting or cooking may be especially important in fantasy literature for children, as food is real, while fantasy is an extension of the real. Writers often resort to the food metaphor, the 'culinary sign', as Louis Marin describes the semiotics of cooking and eating in Perrault's tales of marvel. as a means to discuss identity and belonging. moral character, children's behaviour, power relations and gender roles. As Margaret Visser argues in her study of table manners, 'Eating behaviour is still-and, I would argue, must always remain-guarded, enculturated, ritualized. and even tabooladen' (Visser 1991, p.341). Judgements associated with eating appear as responses to literature, too. as 'wholesome', 'poison', 'satisfying', 'tasteless'.

In her study of food in children's fiction, Wendy R. Katz argues that food in children's literature acts as a 'measure of the child's adjustment to the social order' (Katz 1980. p.193). Perry Nodelman, among many other critics. understands food to function, in part, as a substitute for sex: 'The sensuous delight of these descriptions of food [in a number of classic children's books] reveals that in children's fiction, eating seems to occupy the place that 'sex does in adult fiction' (Nodelman 1992. p. 196). I want to suggest that within children's fantasy, the activities surrounding food are particularly fruitful for tracing changing notions of childhood through history. That is, the adult construction-expressed by the narrator, grown-up characters, or social mores exhibited and promoted in the text-of the child characters (whether human or animal) experiences of hunger and eating. reveal the fantasies of adulthood as much as the pleasures associated with childhood.

Certainly food, taste, flavour, and hunger have always been associated with fantasy literature and the ideals of 
what can be called 'Good' and 'Bad' food. For Georgian rationalists such as Maria Edgeworth. fantasy was literally Bad Food. Edgeworth's opinion, stated in the preface to The Parent's Assistant (first published in 1796) is that a child's mind has limited storage capacity, and that stories of giants and fairies take up space that could be put to better use; though the child may prefer the taste of the fantastic, it is the instructor's duty to control the young reader's palate: 'Why should we vitiate their taste. and spoil their appetite, by suffering them to feed upon sweetmeats?' she asks (Edgeworth [1800]1976 vol. 1, p.xi). Indeed, in the Georgian era, fairy tales were in poor taste. As an anonymous reviewer writing in The Ladies Museum in 1831 noted with satisfaction, 'The days of Jack the Giant-Killer, Little Red Riding-Hood, and such trashy productions are gone by, and the infant mind is now nourished by more able and efficient food.' (quoted in Avery 1992, p.321). 'Bad food'-in the form of any kind of imaginative unreason-should never enter the mind or the mouth of the Rationalist's literary children.

To cite one example from Edgeworth: in 'The Birthday Present', a tale featuring Edgeworth's most famous heroine, a troubled Rosamond questions her mother about birthday celebrations. After a thoughtful silence. Rosamond asks whether her mother could recall Cousin Bell's upcoming birthday, and when she cannot, Rosamond remarks, 'But you never remember about birth-days. mamma: that was just what I was thinking of, that you never remember my sister Laura's birth-day, or-or-or mine, mamma?' When Rosamund's mother demurs and recalls her ability to remember her children's birth dates perfectly well, Rosamond gets to the 'meat' of her concern. She wishes her mother to 'keep' her birthday, that is, to celebrate it in the fashion of a 'great meal', "new playthings', and everyone 'drinking her health". Rosamond's mother purposefully misunderstands the little girl in order to reveal the child's folly, and asks in turn: 'And can Bell eat more upon her birtl?-day than upon any other day?' and whether 'new' playthings are somchow better than old ones? and what logical reasoning could be behind different treatment on a birthday over any other day? (Edgeworth [1800]1976, vol 2, pp.4-7). Rosamond is sure that there must be an answer to these questions. since her desire for a special meal and special treatment is so strong, but she cannot think of one. By the end of the tale, however, birthday festivities are the context for a spoiled child's tantrums and falsehoods, and Rosamond has learned that the 'everyday' love, respect, and meals a child earns by right conduct is worth more than the self-admiration and 'excessive' sentiment and treats that arise from the celebration of a birthday.

A birthday party is also at the heart of the fantasy tales of Christina Rossetti. Rossetti's tales in Speaking Likenesses (1874) marry Edgeworth's rationalist principles (and contain a very Edgeworthian narrator-aunt) of 'good food' for children with the pleasant ideals of literary entertainment-promoted in fantasy especially after Carroll's Alice-in order to create a 'toothsome' and healthful offering. Rossetti's three 'antifantasies' (to use Nina Auerbach and U. C. Knoepflmacher's useful phrase in Forbidden Journeys, 1992, p.317) that make up Speaking Likenesses communicate their moral through tales about conduct related to food, table manners, and social etiquette. In the first story about eight-year-old Flora's birthday party, quarrels over sweets lead to bad tempers and an ensuing dream/fantasy about matters relating to the mouth, including privation, gluttony, and verbal abuse.

From the very first, the problems at Flora's birthday party stem from ungracious behaviour at the table: the children all fight over the sugar-plums and dispute who has eaten more and whose were larger. The party goes from bad to worse, and the children quarrel all afternoon until, finally, Flora enters the yew lane to get away from her guests and discovers a door she has never seen before at the end of it.

Flora enters an enchanted apartment where a number of children are having a birthday feast. When Flora is finally offered some berries and cream, the birthday 'Queen' refuses to let her taste any because 'It's my birthday and everything is mine' (Auerbach and Knoepflmacher 1992. p.333). The children are 'speaking likenesses' of various foibles and childish behaviours first exhibited at Flora's birthday party: pinching. unctuousness, unpleasantness. and unwanted touching, here allegorized by the children called Slime, Sticky, Hooks and Quills. The natural revulsion Flora feels toward these children is also related 
to food, in the case of Slime and Sticky in particular. As Visser notes.

We hate whatever oozes, slithers, wobbles. . . Anglo-Saxons, more squeamish than the French, often find the idea of eating snails as abhorrent as eating frogs, merely because these creatures (when alive) are slimy and slippery; it is the thought of them, not the taste, which is off-putting. (Visser 1991. p.311).

After playing their cruel games, the children sit down to another meal from which Flora is excluded. Here the children indulge gluttonous appetites, gulping

cold turkey, lobster salad, stewed mushrooms. raspberry tart, cream cheese, a bumper of champagne, a meringue, a strawberryice, sugared pine apple, some greengages... Several of the boys seemed to think nothing of a whole turkey at a time: and the Queen consumed with her own mouth and of sweets alone one quart of strawberry ice, three pine apples, two melons, a score, of meringues, and about four dozen sticks of angelica, as Flora counted.

(Auerbach and Knoepflmacher 1992. p.339)

The dream-for of course Flora has fallen asleep and dreamed the nightmare birthday party where horrible and untouchable children reign-does its work, and Flora learns her lesson. as the narrator-aunt makes clear to her nieces, who are tistening to the story as they ply their needles:

\begin{abstract}
And / think if she lives to be nine years old and give another birthday party, she is likely on that occasion to be even less like the birthday Queen of her troubled dream than was the Flora of eight vears old who, with dear friends and playmates and pretty presents, yet scarcely knew how to hear a few trifling disappointments, or how to be obliging and good-humoured under slight annoyances.
\end{abstract}

(Auerbach and Knoepflmacher 1992, p.342)

The folly of Flora's selfish conduct is brought home to her through the dream: she is the Birthday Queen who denies her guests and who demands to be the centre of attention. The Birthday Queen is Edgeworth's nightmare come to life, indeed. Rossetti uses the flexibility of fantasy to comment on the necessary acculturation that little girls must undergo as they mature. In defiance of Carroll, whose little girl is indulged, Flora is disciplined in the ways of eating and entertaining. A glimpse of Edgeworth's gendered moralist vision is revealed in Rossetti's tales, which she, after Carroll and in response to him, reworked within didactic fantasy. As Knoepflmacher comments in Ventures Into Childland,

The children the Aunt dominates [in Speaking Likenesses] thus are more than naive foils to an ironic adult. They are, quite specifically, Victorian girl-readers who have too passively accepted, as far as Rossetti is concerned, their transportations into wonderlands or other realms of 'marvel'.

(Knoepflmacher 1998, p.363)

The third tale in Rossetti's trio (the second is a kind of non-tale) is a Christmas story (the young ladies of the frame tale ask for a 'winter tale' that will be full of 'wonder', linking this request to Carroll's sequel. as Knoepflmacher notes (1998,p.365) that again focuses on food and consumption. A worthy, hardworking widow has sole charge of her young granddaughter. and when the Doctor's young ladies leave their packages behind in Old Dame Margaret's shop, Maggie begs leave to take the parcels to the Doctor's house though it is getting dark, and the way is through the woods on a very cold evening. On her journey, Maggie falls on the ice and hits her head: from this moment her adventures begin. She meets the awful children of the first story-the pincushion boy, the eel-like girl, and so on-who entice her to play with them. Although Maggie would love to play-she has never had any playfellows-she remembers her promise to make haste on her errand, and so refuses them.

Like the cold birds who flutter around her. Maggie is very hungry. She peers into the basket she carries to see if there is something from her grandmother that she can give to the birds. However, there is nothing there except for the Doctor's goodies. Maggie next meets a boy who is all mouth: 'His face exhibited only one feature, and that was a wide mouth.' The unusual and ugly boy demands her food to feed his enormous hunger and starving self. Maggie refuses to be a thief of another's food, although 
she admits her own appetite. After reaching her destination but receiving nothing but a cold thanks for her many pains, Maggie turns bitter as she retraces her steps. Finding three helpless little animals (a pigeon, kitten and puppy), and choosing to nurture them, however, lightens Maggie's heart, and she skips home to be welcomed with love and a modest tea.

And whilst Maggie thawed, and drank tea, and ate buttered toast in Granny's company, the pigeon thawed too, and cooed and pecked up crumbs until it perched on the rail of a chair. turned its head contentedly under its wing, and dropped fast asleep; and the kitten thawed too: and lapped away at a saucerful of milk, till it fell asleep on the rug....

(Auerbach and Knoepflmacher 1992, p.360)

Everyone eats and falls asleep naturally. This sleep of righteousness contrasts with Flora's nightmare that occurs after mistakes with food are made. This last story is about the appropriateness of refusing to eat food that belongs to another, and the reward for this selfless action is simple food delivered by loving hands. This is rather like Alcott's Little Women (1868), where the March daughters give away their Christmas breakfast (it belongs to the immigrant Hummel family by moral right) ultimately to receive a lavisin Christmas dinner as reward. For the March girls, as for Maggie, fasting constitutes a symbolic victory over the needs of the body. (For Lewis Carroll's Alice, by contrast. Wonderland is her meal and she gobbles it up with relish.)

And yet, when the characters do eat. or watch others at table, the flavours within the fantasies of Rossetti and later C.S. Lewis are remarkably like those of Wonderland. When Alice swallows the first potion marked 'Drink me', it has a pleasant taste of 'cherry-tart. custard, pineapple, roast turkey, toffy. and hot-buttered toast' (Carrolf [1865]1992. p.11). Alice is described as a little gir! who is very fond of eating and drinking: her hunger for Wonderland knowledge and her eventual understanding of Wonderland logic-which comes in part by way of eating its food-allows her to assert her authority within the courtroom and claim both a place for herself and ultimately to dismiss her tormentors as meaningless.
Most of the food of Wonderland is ordinary-the cordial tastes of typical English dinner; there are cakes and tarts and toast and tea-but offered in an extraordinary manner. Alice makes her way alone in Wonderland and the food she encounters and eats is within her reach without any adult mediation beyond her own girlish conscience (easily assuaged by ascertaining that the bottle is not marked 'poison', for example). Here, via foodstuffs and appetite, Carroll reveals himself as an anti-didact, urging his little giri to help herself, to assert her independence and taste widely. Rossetti's Flora, by contrast, controls her hunger and fasts when appropriate. In the unpleasant dream-birthday feast, Flora's abstention from eating 'Bad' food connotes her redemption as a 'Good' girl.

Within the Looking-Glass world of Carroll's sequel, hunger, appetite, dinner manners, and conduct at table are all reversed. At dinner, Alice is introduced to the traditional English dinner and therefore cannot eat it:

At last the Red Queen began. 'You've missed the
soup and fish,' she said. 'Put on the joint!' And
the waiters set a leg of mutton before Alice, who
looked at it rather anxiously, as she had never
had to carve ajoint before. 'You look a little shy:
let me introduce you to that leg of mutton, 'said
the Red Queen. 'Alice-Mutton: Mutton-Alice.'
The leg of mutton got up in the dish and made a
little bow to Alice; and Alice returned the bow,
not knowing whether to be frightened or amused.
(Carroll [1871] 1992, p.200)

Alice cannot eat, though she is hungry and the feast is in honour of her coronation. Eating now falls under the aegis of the rules that govern all social interaction: you cannot 'cut' anyone to whom you've been introduced (Carroll [1871]1992, p.200). Looking-Glass world is a world where society extends to include all things. This disordered world is perfectly reflected in the confused dinner party-a social space that in the 'real' world appears to be perfectly organized, and yet which is fraught with scores of taboos and rules which may appear to be illogical: the placement of the spoon and knife, the order of forks, the direction to which food is passed, the placement of hands and elbows, the method of drinking soup. 
Susan A. Walsh calls this coronation party 'a terrifying reversal of Darwinian evolution where legs of mutton and plum puddings dine on human beings' (Walsh 1987 , p.34). Boundaries between eater and eaten completely disappear as the leg of mutton replaces the White Queen in her chair and she disappears into the soup, and the ladie walks toward Alice gesturing for her to get out of its way. The disorder drives Alice mad and she cries out, "I can't stand this any longer!" and in a fit of VERY bad manners. -...jump[ed] up and seized the tablecloth with both hands; one good pull, and plates, dishes guests, and candles came crashing down together in a heap on the floor' (Carroll [1871] 1992,p.204). Alice is not punished for her loss of control; her ultimate authority is acknowledged as she shakes the Red Queen into a kitten, just as she has threatened to do, and then ponders the author of the dream. Carroll answers Alice's question about 'who dreamed it' in the last line of his acrostic poem 'A boat, beneath a sunny sky': finally, it doesn't matter, because, 'Life, what is it but a dream?' (Carroll [1871]1992, p.209).

Unlike the fantasy stories of Carroll and Rossetti, C. S. Lewis's Narnia is resolutely not a dream-scape but a parallel world. When Flora or Alice awakens from her dream. time has passed within the real world (though it does not correspond to the day-long adventures each has experienced), but Narnian years are condensed within parts of seconds of 'real' time. One might expect Narnian food to be unlike the food found in Carroll and Rossetti, yet the same ordinary, 'middle-class' (if food can be classed. which I think it can) comfort food shows up in all three fantasies.

Certainly. Lewis's own love of plain and wholesome English food comes through in the Chronicles of Narniafrom Lucy's tea with Mr. Tumnus (in The Lion the Witch, and the Wardrobe) to Shasta's first Narnian breakfast (in The Horse and His Boy) to the rather more elegant meal Aslan prepares for the evil dwarves who can't appreciate it (in The Last Battle). Lucy's first Narnian meal is worth quoting here:

And really it was a wonderful tea. There was a nice brown egg. lightly boiled, for each of them. and then sardines on toast, and then buttered toast, and then toast with honey, and then a sugar-topped cake.

(Lewis [1950]1996c, p.20)

Brian Sibley comments in his Land of Narnia (written for a young audience) that one of the reasons that Narnia seems so real is that the food is familiar. but one-step better than 'our' food (Sibley 1989, p. 78). I agree with Sibley, and would add this comment to his: buttered toast stays hot and buttery much longer in Narnia than in England (or America)! Shasta is intrigued and satisfied by the proper English/Narnian breakfast he is offered as a sign of friendship upon first entering Narnia: there's porridge and cream and 'bacon and eggs and mushrooms' with hot milk, coffee and the ubiquitous buttered toast.

One exception to the 'homey' English quality of many of the meals and palates of the Narnians (imported and native) is the cuisine of the foreign Calormenes. Here Lewis's 'othering' of different races is made apparent through their food. The dark-skinned Calormenes, who worship false gods, also eat 'Orientalized' food of a vaguely Middle Eastern cast (except for the desserts which are melons and gooseberry fool):

It was a fine meal after the Calormene fashion. I don't know whether you would have liked it or not, but Shasta did. There were lobsters, and salad, and snipe stuffed with almonds and truffles, and a complicated dish made of chicken-livers and rice and raisins and nuts. .

(Lewis 1996b, pp.74-5)

Donald Glover calls the description of the city of Tashban (in The Horse and His Boy) a 'memorable Turkish Delight' (Glover 1981, p.161). and Claudia Nelson argues that Lewis (and Tolkien) 'use food to indicate character, making divisions among the homely, the exotic, and the unwholesome, according to "racial" boundaries (human, witch, hobbit, elf, orc)...' (Nelson 1991, p.204 n73).

For Lewis, the functions of food and taste are not merely mimetic, but also metaphoric in nature, and it is the food itself. as well as the consumers of it, that communicates a moral vision. In the spirit of Edgeworth and Rossetti, food in Narnia is typed as either 'Good' or 'Bad'. The young traitor. Edmund Pevensie, reveals his sins and errors through his indulgence in the "forbidden pleasures 
[of] disobedience wilfulness, and gluttony' (Walsh 1987 . p.35). The White Witch Jadis coerces Edmund to do her bidding through her conjuration of magic, poisoned food. Edmund indicates that Turkish Delight (a confection of little substance) is his favourite thing to eat. The White Witch's Turkish Delight is the most delicious and addictive treat imaginable, and Edmund is powerless to stop himself from gobbling it up greedily, with little concern for correct table manners. Donald Glover compares the honest Lucy at Mr. Tumnus's tea with the treacherous Edmund in his meeting with the White Witch and comments that 'food becomes the principal difference between Edmund and Lucy' (Glover 1981, p. 138). Lucy's polite manners and pity for the poor faun contrast with Edmund's gluttony and disregard for his brother and sisters.

The duplicitous White Witch is an abstemious female eater and is shown ingesting food only once (besides the 'exceedingly expensive, not to say ostentatious, lunch' Uncle Andrew unwillingly provides Jadis in London in The Magician's Nephew (Lewis 1996d, p.111): she eagerly consumes the silver apple from the Western Wild and obtains both her heart's desire (eternal youth) and despair, as promised. The stain of this act of selfishness and disobedience is made litera! on her face as she is marked and defined by the food she eats: 'The juice [of the apple] was darker than you would expect and had made a horrid stain round her mouth...but her face was deadly white, white as salt' (Lewis 1996d, p. 166). Jadis's salt-white visage is certainly an allusion to Lot's wife who, through an act of disobedience. is turned into a pillar of salt.

The consumption of Bad Food-the enchanted Turkish Delight, stolen apples from the Tree of Life-leaves a physical mark that indicates internal corruption. More subtly than in Rossetti's allegorized Sticky and Slimy children. the morally decayed Witch and the fallen Edmund reveal their weakness to the righteous around them who eat only wholesome food. Mr Beaver says about Edmund: - He had the look of one who has been with the Witch and eaten her food. You can always tell them if you've lived long in Narnia, something about their eyes' (Lewis I 996c, p.81). And Edmund's discomfort from his gluttony reflects his moral 'dis-ease': 'Edmund was already feeling uncomfortable from having eaten too many sweets, and when he heard that the Lady he had made friends with was a dangerous witch he felt even more uncomfortable' (Lewis 1996c, p.43). Edmund cannot enjoy the good meal that the Beavers prepare because he has the 'taste' for enchanted food: '.. there's nothing that spoils the taste of good ordinary food half so much as the memory of bad magic food' Lewis's narrator (akin to Rossetti's aunt-narrator) reminds readers (Lewis 1996c, p.84).

The most significant meal in the first book of the Chronicles of Narnia involves table manners, taste, and the closest connection between Narnia and the 'real' world of war-ravaged England. Father Christmas, a Christian (bordering on secular) figure of generosity, has come to Narnia at last, indicating the weakening power of Jadis and prefiguring the arrival of Aslan. As is his wont in the 'real world', Father Christmas brings gifts, good cheer, and good food for the Narnians on the 'right' side. The days of Narnian rationing-poignant for the refugee Pevensie children and unlike real-life 1950s England, in which food rationing was still in effect-are over, and a little band of woodland creatures gathers together to celebrate:

A little way off at the foot of a tree sat a merry party, a squirrel and his wife with their children and two satyrs and a dwarf and an old dog-fox. all on stools round a table. Edmund couldn't quite see what they were eating, but it smelled lovely and there seemed to be decorations of holly and he wasn 't at all sure that he didn't see something like a plum pudding. At the moment when the sledge stopped, the Fox, who was obviously the oldest person present, had just risen to his feet, holding a glass in his right paw as if he was going to say something. But when the whole party saw the sledge stopping and who was in it, all the gaiety went out of their faces. The father squirrel stopped eating with his fork halfway to his mouth and one of the satyrs stopped with his fork actually in his mouth, and the baby squirrels squeaked with terror.

(Lewis 1996c, p.107)

The Witch immediately demands to know how to interpret this scene. When no one answers her. she responds in 
anger. "What is the meaning of all this gluttony, this waste, this self-indulgence? Where did you get all these things?' (Lewis 1996c, p.107) Her evil purpose, which is to keep Narnia in perpetual winter but to deny Christmas, is reflected in her relationship to food. For the Witch, a Christmas feast represents gluttony, excess, wastefulness and needless self-gratification. An abstemious, cold dictator. the Witch rejects the pleasures of the flesh and of social felicity- of which eating is one. (Dr. Seuss's Grinch, of course, is cut from the same cloth.) The Old Fox's attempt at politeness (drinking her health) fails, and the truth-telling creatures, led by the youngest among them, refuses to deny Father Christmas's arrival. Though they are punished harshly, like Rossetti's Flora and Maggie, the animals do not fall from the ways of right conduct, and their frozen attitudes of interrupted celebration testify to the power and significance of communal gathering. The Witch has won only temporarily, and the creatures will live to finish their ritual meal and to celebrate Christmas another day.

Ironically, it is Lewis's evil White Witch-rather than a wise human-who is the true mouthpiece of the Rationalist's ideologies of usefulness and reason. The creatures gathered in fellowship around the Christmas table can no more explain the meaning of their happiness (Father Christmas's coming-that is, Christ's coming) to the unbeliever Jadis, than Edgeworth's little Rosamond can explain to her mother why it is that she desires special attention on her birthday. In fact, it is the abstemious Witch, stern narrator-aunt, and authoritative Red Queen who determine the terms of the meaning of food in these fantasy texts for children. The self restraint of good Georgian and Victorian girls is set against the self-induigence of gluttonous children. Food is labelled 'Good' or 'Bad'; literature is labelled 'wholesome' or 'garbage.' But just as in the Looking-Glass world, we can invert these self-same conclusions and re-imagine the food metaphor as Lewis's method for articulating a different community from that of the Victorians represented by Rossetti. In didactic fantasy, child readers are encouraged to identify with the community of adult eaters. In order to enter that social sphere, girls in particular must adopt the eating protocols of adults (in terms of what is eaten, when, how much, and in what manner). In Lewis, however, child characters with in the fantasy world ultimately reject the sterility of the adult community (represented by the Witch), and celebrate with the talking animals, dwarves, fauns and other creatures of Narnia. Although Alice's dream can be half-experienced by her grown-up sister, Narnia functions essentially as a child's worid; significantly, one can only enter Narnia as a child or with a child. The hungry Victorian child remains, for the most part, either an incomplete aduit, or preferable to adults. The child in Narnia, however, reflects the nostalgic 'healthy' appetite of English youth during the war years for adventures, alliances, communal celebrations-and butter!

\section{END NOTES}

1. Maria Nikolajeva's book From Mythic to Linear Time in Children's Literature, offers a sustained and fascinating view of the ritual function of food in children's literature. She makes the point that an important function of food within children's literature is as a symbol of community (p.16).

2. J. M. Barrie's parallel realm, Never Land (in the Peter Pan play and novel) is somewhat unusual as its food is all imaginary. That this food is satisfying only to Peter-Never Land's one actual native-highlights the distinction between the imaginative play of children who will grow up, and the somewhat desperate actions of one who will not leave childhood. See also Part Three. 'The culinary sign in the land of fairies and ogres', in Marin's Food for Thought, pp.117-186.

3. See Nikolajeva for a useful listing of critics of children's literature who link food with sexuality $(2000$, p. 11$)$.

4. Nikolejeva $(2000$, p. 129$)$ believes that the largesse of the Tumnus table, in the form of two eggs, points directly to the rationing-one egg every other week- endured by the British during and after the war. See also Glen Mynott's discussion of Lewis's brother to rationing in his contribution to this issue of Papers 


\section{REFERENCES}

\section{Primary texts}

Lewis. C.S. (1966a) 'On Stories', Of Other W'orlds. New York, Harcourt, Brace, Jovanovich.

Lewis, C.S. (1996b) The Horse and His Boy. London, The Folio Society.

Lewis. C.S. (1996c) The Lion, the Witch and the Wardrobe. London, The Folio Society

Lewis. C.S. (1996d) The Magician's Nephew. London, The Folio Society.

\section{Secondary texts}

Auerbach, N. and Knoepflmacher U (eds) (1992) 'Introduction' to Forbidden Journeys: Fairy Tales and Fantasies by Victorian Women W'riters. Chicago. Chicago University Press.

Avery, G. (1992) 'Fairy Tales with a purpose', Reprinted in D.J. Gray (ed) Alice's Adventures in Wonderland. New York, W. W. Norton. pp.321-324.

Biasin, G.P. [1991] (trans. 1993) The Flavors of Modernity: Food and the Novel. Princeton, Princeton University Press.

Carroll. L. [1865] (1992) D. J. (Gray (ed) 2d. ed. Alice's Adventures in Wonderland. New York, W.W. Norton.

Edgeworth. M. [1800] (1976) 'Preface' and 'The birthday present', in The Parent's Assistant. 2 vols. New York. Garland.

Egoff. S.A. (1988) Worlds Within: Children's Fantasy from the Middle Ages to Today. Chicago and London. American Library Association.

Glover, D. E. (1981) C.S. Lewis: The Art of Enchantment. Athens, Ohio: Ohio University Press.

Katz. W. R. (1980) 'Some uses of food in children's literature', Children's Literature in Education 11. 4:192-99.
Knoepflmacher, U. C. (1998) Ventures into Childland: Victorians, Fairy Tales and Femininity: Chicago, University of Chicago Press.

Langford, J. (1996) 'Sitting down to the sacramental feast: food and cultural diversity in The Lord of the Rings', in G. Westfahl, G. Slusser \& E. S. Rabkin (eds) Food of the Gods: Eating and the Eaten in Fantasy and Science Fiction. Athens and London. University of Georgia Press, pp.117-141.

Mann, L. (1986) trans. Mette Hjort Food for Thought. Baltimore, Johns Hopkins University Press.

Nelson, C. (1991) Boys will be Girls: The Feminine Ethic and British Children's Fiction, 1857-1917. New Brunswick, Rutgers University Press.

Nikolajeva, M. (2000) From Mythic to Linear Time in Children's Literature. ChLA andScarecrow Press.

Nodelman, P. (1992) The Pleasures of Children's Literature. New York, Longman.

Sceats, S. (2000) Food, Consumption and the Body in Contemporary Women's Fiction. Cambridge, Cambridge University Press.

Sibley, B. (1989) The Land of Narnia. New York, Harper and Row.

Visser, M. (199l) The Rituals of Dinner: The Origins, Evolution, Eccentricities, and Meaning of Table Manners. New York. Grove Press.

W'alsh, S. A. (1987) 'Darling mothers, devilish queens: the divided woman in Victorian fantasy' in Victorian Newsletter 72: 32-36. 


\section{BIOGRAPHICAL NOTE}

Lymne Vallone is Professor of English at Texas A\&M Liniversity. where she teaches literature for children and adolescents and undergraduate and graduate levels. Her most recent book, a study of the girlhood of Queen Victoria and (jeorgian girlhood more generally, is entitled. Becoming Victoria (Yale University Press, 2001). She is currently' Co-Associate General Editor, with Lissa Paul, of the first Norton Anthology of Children's Literature (General Editor, Jack Zipes).

\section{$\rightarrow \gg \cdot G$}

\section{EDITORIAL}

(Continued from page 4)

perhaps 'egged' on by long-term rationing in 1950 s Britain. deliglus in his child characters" healtly appetites. and celelrates children's pleasure in food. community and new experiences.

Glen Mynott and David Rudd both focus on Lewis's literary stylistics to argue that he is a consciously controlling writer purveying a particular brand of British. conservative ideology. which. Rudd suggests, contains the seeds of its own unmaking: the determination to coerce provokes resisting readers later in life.

The final contribution to this edition is provided by Alan Read, whose current research combines performance and animals. What now exists as a paper originally took the form of a multi-media performance which explored a range of subjects including the act of reading a child to sleep: children's departures from the everyday through sleep. performance and play; abduction and seduction: inthropomorphism and the child. and the meaning of fur. His wide-ranging use of social. cultural and performance lheories results in striking readings of Lewis's deeply familiar The linn, the Witch ant the Wardrobe, and on genres and issites often discussed by children s literature specialists. The connections he makes bring to the fore a theme which rums through all of these papers: while C.S.
Lewis embodied and in the Chronicles of Narnia espoused the mainstream, middle-class, conservative values of 1950s Britain. with the passage of time he no longer represents the dominant ideology. Efforts to promote more equal societies. increasingly secular lifestyles. and better understanding of the processes and effects of interpellation. have changed the conditions in which the texts are read precisely in the areas that mattered most to him and for which he used them as vehicles of instruction. The effect of this may be, as David Rudd suggests. to make the texts deconstruct, but the likelihood is that, on the coat-tails of Pullman, Rowling and Tolkien. through the enthusiasm of a generation of parents for many of whom the books were as potent as they were for Francis Spufford, and with the stimulation provided by the new fitm and all its spin-offs. we will still be teaching the Chronicles of Narnia for many years to come.

Kimberley Reynolds

\section{BIOGRAPHICAL NOTE}

Kimberley Reynolds is Professor of Children's Literature at the University of Surrey Roehampton in London. where she teaches on the MA in Children's Literature. supervises many doctoral students, and directs the awardwinning National Centre for Research in Children's Literature. She has published in the areas of children's literature. Victorian literature, childhood studies and women's studies: her most recent books include Frightening Fictions (2001). written with Geraldine Brennan and Kevin McCarron. Representations of Childhood Death ([2000] co-edited with Gillian Avery) and Children's Book Publishing in Britain since 1945 ([1999] co-edited with Nicholas Tucker). 